\title{
Genetic Load in the Chicken
}

\author{
Ikuo OKada ${ }^{1)}$, Hiroyuki Bansho ${ }^{2)}$, Shigeo Aoyama ${ }^{2)}$ and Takuzo Tsue ${ }^{2)}$ \\ ${ }^{1)}$ Faculty of Fisheries and Animal Husbandry, Hiroshima University, \\ Fukuyama 720 \\ ${ }^{2}$ Miyoshi Branch of Hiroshima Prefectural Animal Experiment Station, \\ Miyoshi 728
}

The genetic load is expressed by the decrease of average fitness of a population, which is brought about by deleterious alleles maintained by recurrent mutation or by balanced polymorphism. Inbreeding depression gives us an estimation of genetic load. From published data, PISANI and KERR ${ }^{1)}$ estimated the average number of lethal equivalents per zygote in chickens, swine and cattle. Thereafter, several studies on genetic load were reported in cattle $^{2,3)}$, goat ${ }^{4)}$ and quail ${ }^{5-8)}$.

The present study was undertaken to estimate the amount of genetic load in chickens by using information about the inbreeding depression on hatchability.

\section{Materials and Methods}

Data employed in this investigation were collected from three lines under an inbreeding project at the Miyoshi Branch of Hiroshima Animal Experiment Station, Miyoshi. The objective of the project was to develop inbred lines from strain- or breed-crosses. Three strains of White Leghorn (WL), A, B and, C, and one strain of Rhode Island Red (RIR) were used for the production of base populations. The line coded $\mathrm{K} 1$ comprised descendants from crossbreds of White Leghorn A and B, and K2 orginating from WL-B $\times W L-C$. The line K3 was developed from backcrosses of WL-C $\times$ RIR crosses to WL-C.

The breeding program consisted of rearing 20 males and 100 females and of selecting one male and twenty females for each line. However, the population size of K3 was doubled in later generations (Table 1). All mates were, therefore, full- or half-sibs, and matings were performed by artificial insemination. Selection was carried out on the basis of egg production up to 300 days of age. Hatchability was measured as the percentage of hatched chicks to fertile eggs.

The average number of lethal equivalents per bird was estimated according to MorTon et al. ${ }^{9)}$ by the following equation:

$$
-\log _{e} S=A+B F \text {, }
$$

where $S$ represents the proportion of survivors and $F$ the inbreeding coefficient. $A$ evaluates the detrimental effects due to the lethal equivalents in random mating population and $B$ is the expression of the hidden lethal equivalents per gamete. Then, $2 B$ represents the lower limit of lethal equivalents per zygote and $2(A+B)$ the upper limit.

\section{Results and Discussion}

Mean values of hatchability and inbreeding coefficient for each generation are shown in 
日本家禽学会誌 16 巻 1 号 (1979)

Table 1. Changes in hatchability and inbreeding coefficient in the three inbyed lines

\begin{tabular}{lllllll}
\hline \multirow{2}{*}{ Line Measurement } & \multicolumn{5}{c}{ Year of hatching } \\
\cline { 2 - 7 } & 1973 & 1974 & 1975 & 1976 & 1977 \\
\hline \multirow{2}{*}{ K1 } & No. of dams & 19 & 24 & 17 & 18 & 30 \\
& Hatchability & 71.1 & 81.1 & 82.3 & 74.7 & 71.9 \\
& $F$ value (\%) & 0 & 15.1 & 25.2 & 38.0 & 41.8 \\
\hline \multirow{2}{*}{ K2 } & Ho. of dams & 15 & 23 & 17 & 18 & $-1)$ \\
& Hatchability & 84.4 & 88.6 & 81.2 & 72.1 & - \\
\hline \multirow{2}{*}{ K3 value (\%) } & 0 & 14.7 & 26.3 & 33.2 & - \\
\hline No. of dams & - & 23 & 35 & 39 & 58 \\
& Hatchability & - & 87.7 & 88.9 & 85.3 & 67.9 \\
& $F$ value (\%) & - & 0 & 16.8 & 27.6 & 34.5 \\
\hline
\end{tabular}

1) Discarded.

Table 1 . The levels of hatchability remained constant in early generations, but decreased gradually in later generations as inbreeding increased. Because preliminary analyses revealed significant variation of hatchability between years, all analyses were performed on the basis of within-years within lines.

The regression coefficients of hatchability on the inbreeding coefficient were -0.270 , -0.869 and -0.519 for the lines $\mathrm{K} 1, \mathrm{~K} 2$ and $\mathrm{K} 3$, respectively. Among them, only the regression in the line K2 was significant statistically. Analysis of covariance showed that differences between these regressions were not significant, but the pooled regression for all lines was significant. The estimate of pooled regression was -0.528 . SHOFFneR ${ }^{10)}$ reported a decline of 0.44 percent of hatchabiliy for each percent of inbreeding. Similar results were also reported by DüzGüNES ${ }^{11)}$ and Blow and GLAZENER ${ }^{12)}$, namely -0.44 and -0.37 , respectively. The present results are in close agreement with those results.

The amount of genetic load in terms of lethal equivalents are given in Table 2. The lower and upper limits of lethal equivalents per zygote differed considerably among the lines, ranging 0.84 to 2.92 for the lower limit and from 1.22 to 2.92 for the upper limit. The pooled estimates for the lower and upper limits were 1.74 and 1.86 , respectively. The values of $B / A$ ratio were relatively high except for the line $\mathrm{K} 1$.

PISANI and $\mathrm{KERR}^{1)}$ reported that the lethal equivalents affecting hatchability were 1.69 in White Leghorns and 5.68 in Barred Plymouth Rocks and the $B / A$ values were low. The

Table 2. Genetic load estimated from hatchability

\begin{tabular}{crlccc} 
Line & $A$ & $B$ & $B / A$ & \multicolumn{2}{c}{ Lethal equivalent per zygote } \\
\cline { 5 - 6 } & & & & Lower limit & Upper limit \\
\hline K1 & 0.191 & 0.420 & 2.199 & 0.840 & 1.222 \\
K2 & -0.052 & $1.458^{*}$ & $-1)$ & 2.916 & $2.916^{2)}$ \\
Pooled & 0.053 & 0.863 & 16.283 & 1.726 & 1.832 \\
\hline
\end{tabular}

1) See text. 2) $A$ was regarded as zero. $* \mathrm{P}<0.05$. 
lethal equivalents obtained in the present studies were not so different from those estimates. However, an unexpected result was obtained in the values of $B / A$ ratio. High values of $B / A$ were observed for the $\mathrm{K} 3$ and the pooled estimates, which were 16.28 and 14.28, respectively. Furthermore, in the line $\mathrm{K} 2$ the $A$ value was negative, suggesting that it was practically zero and implying that the $B / A$ ratio of line $\mathrm{K} 2$ would also be very large.

As for the relative contributions of mutation and balanced polymorphism to genetic load, WALLACE $^{13)}$ pointed out that large values for $B / A$ suggest recurrent mutation and small values polymorphism. Although the base populations of lines K1 and K2 were both crossed by the same strain, WL-B, the $B / A$ ratio differed markedly, suggesting the existence of different mechanisms regarding the genetic load. Further studies are required to decide whether the difference was actually due to the existence of different mechanisms or attributable to chance phenomenon namely the deviation caused by the small number of samples.

\section{Summary}

Three inbred lines $\mathrm{K} 1, \mathrm{~K} 2$ and $\mathrm{K} 3$ were developed from crossbreds by one-sire sib matings. The mean inbreeding coefficients of the lines ranged from 0.33 to 0.42 for the last generation. Regression coefficients of hatchability on inbreeding coefficient ranged from -0.27 to -0.87 for the individual lines, and -0.53 for the pooled estimate.

The estimated lower and upper limits of lethal equivalents per zygote were 0.84 to 2.92 and 1.22 to 2.92 , respectively. The estimated values of $B / A$ ratio were high in two of the three lines, and the pooled estimate was also as high as 14.28 .

\section{References}

1) Pisani, J.F. and W. E. Kerr: Genetics, 46, 773, 1961.

2) Conneally, P. M., W. H. Stone, W. J. Tyler, L. E. Casida and N. E. Morton: J. Dairy Sci., 46: 232, 1963.

3) Shotake, T. and K. Nozawa: Japan. J. Zootech. Sci., 39, 180, 1968.

4) Shotake, T.: Japan. J. Zootech. Sci., 42: 409, 1971.

5) Sittmann, K., H. Abplanalp and R. A. Fraser: Genetics, 54, 371, 1966.

6) Shinjo, A., Y. Mizuma and S. Nishida: Japan. Poultry Sci., 8, 231, 1971.

7) Shinjo, A., Y. Mizuma and S. Nishida: Japan. Poultry Sci., 9, 254, 1972.

8) Kawahara, T.: Ann. Rep. Nat. Inst. Genet. (Japan), 26, 76, 1976.

9) Morton, N. E. and J. F. Crow: Proc. Nat. Acad. Sci., 42, 855, 1956.

10) Shoffner, R. N.: Poultry Sci., 27, 448, 1948.

11) Düzgünes, O.: Poultry Sci., 29, 227, 1950.

12) Blow, W. L. and E. W. Glazener: Poultry Sci., 32: 696, 1953.

13) Wallace, B.: Genetic Load. Its Biological and Conceptual Aspects. Prentice-Hall, Inc., Englewood Cliffs, N.J., 1970. 


\section{鶏における遺伝的荷重

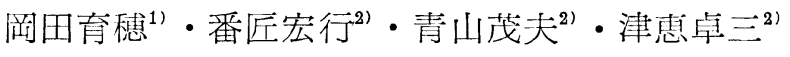 \\ 1) 広島大学水畜産学部, 福山市 720 \\ 2）広島県立畜産試験場三次支場，三次市 728}

系統閌又は品種間交雑群より，一雄家系内の全きょう だい又怙半きょうだい交配によって造成した K1，K2 及 びK3 の 3 近交采について, ふ化率の近交退化及び遗伝 的荷重を推定した。各系統の最終世代の平均近交係数注 0.33〜0.42であった。近交係数 $1 \%$ 当りのふ化率の近 交退化注 0.27 ０.87\% で，3采統究こ夕にして推定寸
ると $0.53 \%$ であった。

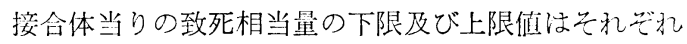
$0.84 \sim 2.92 ， 1.22 \sim 2.92$ であった。荷重比 $B / A$ は 3 采 統のうち 2 系統で高い值安示した。また，3系統をこみ にした值でも 14.28 と高い值が得られた。

（家禽会誌，16，35３8，1979） 